\title{
Evaluating the Effectiveness of Incentives to Improve HIV Prevention Outcomes for Young Females in Eswatini: Sitakhela Likusasa Impact Evaluation Protocol and Baseline Results
}

\author{
Marelize Gorgens \\ World Bank Group \\ Andrew Longosz ( $\square$ aflongosz@gmail.com ) \\ World Bank Group \\ Sosthenes Ketende \\ World Bank Group \\ Muziwethu Nkambule \\ National Emergency Response for HIV/AIDS \\ Tengetile Dlamini \\ National Emergency Response for HIV/AIDS \\ Mbuso Mabuza \\ National Emergency Response for HIV/AIDS \\ Kelvin Sikwibele \\ IHM Southern Africa \\ Vimbai Tsododo \\ IHM Southern Africa \\ Mthokozisi Dlamini \\ IHM Southern Africa \\ Futhie Dennis-Langa \\ Independent \\ Wendy Heard \\ World Bank Group \\ Andrea Low \\ Independent \\ Pandu Harimurti \\ World Bank Group \\ David Wilson \\ World Bank Group \\ Khanya Mabuza \\ National Emergency Response for HIV/AIDS
}


Damien de Walque

World Bank Group

\section{Research article}

Keywords: CCT, Eswatini, Education, Females, HIV, Adolescence, cash-incentivised

Posted Date: October 16th, 2020

DOI: https://doi.org/10.21203/rs.3.rs-28185/v5

License: (c) (1) This work is licensed under a Creative Commons Attribution 4.0 International License. Read Full License

Version of Record: A version of this preprint was published on October 22nd, 2020. See the published version at https://doi.org/10.1186/s12889-020-09680-8. 


\section{Abstract}

Background: Eswatini continues to have the highest prevalence of HIV in the world, and one of the highest HIV incidences among adult populations (aged 15-49). This analysis reports on both key elements of study design/protocol and baseline results from an impact evaluation of an intervention incentivizing (i) initiation, enrolment, attendance or completion of some form of education, and (ii) lower risk sexual behaviour.

Methods: The impact evaluation employs a two by two factorial design in which participants are enrolled in either the incentive for education arm ('education treatment arm' providing a conditional cash incentive) or the control arm ('education control arm'). In each of these arms, $50 \%$ of participants were randomized to also be eligible for selection - three times a year - to participate in a conditional raffle conditional on testing negative for curable STIs (syphilis and Trichomonas vaginalis).

Results: Baseline recruitment and screening occurred in 2016 when a total of 6,055 individuals were screened of which 4,863 participated in the baseline survey, and 4,819 individuals were randomized into one of the study arms. The baseline prevalence of HIV, Trichomonas vaginalis, and syphilis among adolescent girls and young women $8.20 \%(397 / 4,840), 3.31 \%(150 / 4,533)$ and $0.17 \%(8 / 4,830)$ respectively.

Conclusions: An educational cash incentive and raffle incentive impact evaluation that addresses adolescent girls and young women who are in-education and out-of-education has the potential to reduce HIV risk in adolescent girls and young women in Eswatini.

Name of the registry: Pan African Clinical Trials Registry

Trial registration number: PACTR201811609257043

Date of registration: May 11, 2018 'Retrospectively registered'

URL of trial registry record: $h t t p s: / / p a c t r . s a m r c . a c . z a / T r i a \mid D i s p l a y . a s p x ? T r i a l I D=4685$

\section{Background}

The highest rates of HIV infection are in southern Africa, with more than $1 \%$ of the population per year becoming infected in Botswana, Lesotho and Eswatini.(1) There are 6 countries (Botswana, Lesotho, Namibia, Eswatini, South Africa, and Zimbabwe) that have HIV prevalence of more than $10 \%$ of the entire population.(1) In 2015, Eswatini had an estimated 13,910 new HIV infections, 263,040 people living with HIV (PLHIV), and 5,890 HIV/AIDS related deaths.(2) Some of the main factors associated with transmission of HIV in Eswatini include: low prevalence of male circumcision; multiple, long-term concurrent sexual relationships; early sexual debut and intergenerational sex; low condom use, especially in long-term sexual partnerships; lack of family and community support; and multiple structural factors. 
The three main structural factors that influence HIV incidence include income inequality, gender inequality, transactional sex and education.(4-7) Income inequality has been shown to be a major contributor to sexual risk in women in Eswatini.(8) Eswatini is classified as a lower Middle Income country by the World Bank.(9) Yet, Eswatini has one of the highest levels of income inequality in the world: despite it being a lower middle income country, $63 \%$ of the population living on less than $\$ 2$ per day.(9) The poor economic prospects for young women contribute to the increasing prevalence of intergenerational and transactional sex, particularly as young women develop desires and needs consistent with modern expectations of lifestyle. A qualitative study of girls in rural areas of Eswatini found that lack of access to education and employment, and food insecurity often pushed young women into intergenerational partnerships where there was the potential for economic gain.(7) The Ministry of Education of Eswatini provides both Comprehensive Sexual Education and Information and Life Skills education within the schools' syllabi. However, school fees and other contextual considerations may limit the ability of adolescent girls and young women from attending school. Therefore, overcoming economic barriers will be important for adolescent girls and young women to gain an understanding of reproductive health and sexual transmitted disease prevention. Additionally, gender-based violence is a widespread problem in Eswatini where the United Nations Populations Fund (UNFPA) estimates that 1 in 3 females experienced some form of sexual abuse by the age of 18 years, and $48 \%$ of women report to have experienced some form of sexual based violence in their life time.(10)

There have been mixed results from recent cash incentive studies for HIV prevention and their impact on HIV and other sexually transmitted infections. Evidence obtained from cash incentive studies show that cash incentives may reduce HIV $(11,12)$ and STI (sexually transmitted infection) or HSV-2 (herpes simplex virus 2) incidence(11-14) but not all studies demonstrate significant reductions.(15) Additionally, few studies currently focus on out-of-education young women(11) while this group could benefit greatly from cash incentives for HIV prevention as well as more broadly to improve their wellbeing. One important limitation across cash transfer studies are that several of these studies only include girls already enrolled in school and focus on urban areas. $(13,15)$ Additionally, raffles have also been proposed and evaluated as a financial incentive to reduce STIs. (12) However, raffles have not been evaluated in addition to education incentives to determine if there is a compound effect of these cash incentives.

The Sitakhela Likusasa Impact Evaluation rationale and study design combines the study strengths of these 5 studies: it covers a large age range, includes urban and rural settings, and multiple intervention arms. The four intervention arms for the study follow a $2 \times 2$ factorial design and are presented in Figure 1 .

Given the number of countries with cash incentive programmes in place, undertaking studies to assess the impact of cash incentives on HIV incidence reduction for countries with generalized HIV epidemics is important.(16) This impact evaluation will provide complementary data to the studies detailed above, including the most vulnerable girls (education dropouts) and those with poor education outcomes prior to incentives. Our hypotheses are 1) that cash incentives conditional on education attendance will allow girls to continue or return to places of education and reduce high risk sexual behaviour, and 2) that raffle based incentives to girls conditional on a negative curable STI status will reduce risky behaviour, by 
providing incentives to minimise risk. Analysis in this report aims to describe key aspects of the overall protocol design of the study and report baseline results on key risk behaviours and sexual reproductive health outcomes.

\section{Methods}

\section{Study design and study population}

This study was designed to assess the impact of incentives for education attendance/enrolment and remaining STI negative on HIV incidence among HIV negative adolescent girls and young women (AGYW) aged 15-22 at baseline. AGYW were eligible for education enrolment at the primary, secondary, or tertiary, provided informed consent (or had a legal guardian to do so), consented to HIV testing, consented to a urine collection for trichomonas confirmation testing and consented to blood work and regular vaginal swabs for STI testing. The study included AGYW who dropped out of education but were still eligible to return, in order to assess whether incentives could help overcome other factors driving education dropouts. Because of the high HIV-1 incidence amongst AGYW, this evaluation was designed to assess the impact and cost-effectiveness of two different incentives - (a) conditional cash incentives that were conditional on education attendance among AGYW aged 15-22, and (b) raffle incentives for which raffle enrolment was conditional on being negative for curable STIs (syphilis and Trichomonas vaginalis). The primary outcome was HIV-1 incidence at 3 years after study enrolment. Secondary outcomes included Trichomonas vaginalis and syphilis prevalence at endline, and changes in reported sexual behaviours between baseline and endline. Additional outcomes included education enrolment and attendance and graduation rates, cost-effectiveness of cash incentives in terms of HIV prevention, cash incentive costeffectiveness on educational outcomes, and the effects of a raffle incentive on enhancing a cash incentive intervention.

In order to investigate the impact of cash incentives on HIV incidence the study used a 2 X 2 factorial design to allow for a more efficient use of study resources by reducing the required sample size. At a cluster level, $50 \%$ of the participants in the treatment clusters will receive a cash incentive for education, and at the individual level within each treatment arm, $50 \%$ of the participants will be enrolled in a raffle conditional on testing negative for curable STIs. The aim was to enrol, from November 2015 to April 2016, 4,300 girls in 166 randomly selected census enumeration areas (EAs). Three-stage sampling and randomization took place: first, EAs were filtered, randomly selected and randomly allocated to either education treatment or education control arms (50\% in the treatment arm and $50 \%$ in the control arm); second, households with potential participants were randomly identified and all eligible participants within those households were invited to enrol in the study; and third, all enrolled participants were randomly allocated to either the raffle treatment or raffle control arms. For the EA-level sampling, we first selected, from the universe of all EAs in Eswatini, a subset of EAs that met specific conditions: EAs with both a population density of at least 100 and with a female population of at least 200 (based on results from the 2007) census. Furthermore, EAs that were within or adjacent to the EAs where the Orphans and Vulnerable Children (OVC) impact evaluation (a study evaluating unconditional cash transfers for 
orphans and vulnerable children) was taking place, were excluded. The second stage of EA sampling involved stratified random sampling of 400 EAs (20\% urban EAs and $80 \%$ rural EAs). Then 166 EAs were randomly sampled from the 400 EAs using a random number generator and allocated to education treatment or education control arms. Because EAs were oversampled (i.e. more than the 166 EAs needed) treatment and control EAs that were adjacent to each other could be and were replaced (through random selection) with another of the 400 already-randomly selected EAs (an urban EA would replace another urban EA, and so on). This resulted in treatment and control EAs that were neither adjacent to the OVC study EAs, nor immediately adjacent to each other.

For the participant-level random selection, the household listing from the 2007 census was used. Where the household listing from the census was not available, a new household listing was done. In each selected EA, 'seed' households were randomly selected using geospatial sampling. This sampling process involved overlaying the selected EA map over Google Earth, and randomly dropping a location pin in that EA using geospatial analysis software. The household closest to the pins was sampled first, and then every $4^{\text {th }}$ household after that. The aim was to keep sampling households (and potential participants) until, within each EA, there would be 13 AGYW who were attending education at the time of enrolment into the study and 13 AGYW who were not in education. Achieving this target of 26 participants per EA, was difficult. Sampling amongst the initial set of 166 EAs did not yield the targeted 4,300 AGYW. The two main reasons for having to use additional EAs were 1) difficulty of enrolling out of education AGYW, and 2) difficulty recruiting urban AGYW. Therefore, additional EAs were randomly selected from the $400 \mathrm{EAs}$ initially sampled during the first stage of EA sampling. An additional 127 EAs were added to ensure there was a sufficient number of urban and out of education AGYW enrolled in the study, using the same conditions as for the first 166 EAs and ensuring that the $80 / 20 \mathrm{rural} / \mathrm{urban}$ split was maintained and that treatment and control EAs would not be adjacent to each other. Once participants' HIV status was determined and they opted to enrol into the study, they were randomly allocated to a raffle treatment arm or raffle control arm, creating 4 sub-arms: education only sub-arm, education-and-raffle sub-arm, raffle only sub-arm and no intervention sub arm (see Figure 2).

\section{The education cash incentive intervention}

To better understand what interventions might be most useful in Eswatini, we reviewed relevant literature and discussed feasibility and policy relevance of different incentives with colleagues at National Emergency Response for HIV/AIDS (NERCHA). Based on our discussions we found there to be a larger effect of cash incentives on education outcomes with monitoring and enforcement of the conditionality than simply providing unconditional cash transfers.(16)

The initial design of the intervention was that cash incentives, conditional on either of the following criteria, would be provided throughout the intervention period:

a. E200 ( 13.40 USD) for enrolling in primary or secondary education in a given education year 
b. E400 ( 26.80 USD) per education term for attending more than $80 \%$ of their classes each education term over the study implementation period

c. For a randomly selected sub-sample of the participants: E1000 ( 67.00 USD) for the winners of a raffle in which those who tested negative for two curable STIs (Trichomonas vaginalis and syphilis) were entered

These amounts were decided in consultation with the government of Eswatini, balancing the need to propose amounts that would provide strong enough incentives while maintaining a transfer size reasonable within the Eswatini context and that could potentially be scaled-up by the government.

After the first year of implementation, we received feedback from the Ministry of Education's regional guidance officers that there were several AGYW who attended upgrading classes and not traditional education. Older AGYW within our study population also attended upgrading classes, or short courses, or university or other vocational training and they were being excluded from receiving a cash incentive for attending some form of education. Based on this information we determined that from year 2 of implementation onwards, attending upgrading classes, short courses, university or vocational training should all be considered as being eligible for cash incentives. In addition, the midline data collection effort revealed that one of the main factors of AGYW not attending education or enrolling in education were lack of registration fees. Therefore, we also designed an added incentive to pay the education registration fees of all AGYW in the education treatment arm who were out of education as of midline data collection. Consequently, after the first year of study implementation (2016), a protocol amendment was approved whereby it was clarified how incentives for other forms of education than formal education would be paid to participants in the education treatment arm, as follows:

- Education incentive for initiating and completing upgrading classes:

- Enrol for upgrading classes in Eswatini; then receive E700 ( 46.81 USD)

- Apply for O level exams; then receive E700 ( 46.81 USD)

- Education incentive for initiating and sitting for exams at University, vocational school or technical college:

- Register at University or College within Eswatini for 2016 and/or 2017; then receive cash incentive of E700 ( 46.81 USD) per year

- Sit for the annual exam at the end of the year; then receive cash incentive of E700 ( 46.81 USD) per year

- Education incentive for initiating and completing a short course of any kind:

- Initiate attendance at short course during 2016 and/or 2017 through proof of payment; then receive a cash incentive of E700 ( 46.81 USD) per course

- Complete the short course; then receive a cash incentive of E700 ( 46.81 USD) per course 
- Education incentive for participants returning to education in 2018 who were out-of-education in 2017

- Enrol to return to a public education or for an upgrading class or register for a public University or College or to attend a short course; then apply for your 2018 education fees, to a limit of E2,900 ( 193.94 USD) for the year, to be paid directly to the education, college or university where registered.

Payments were made using MTN Mobile Money for participants 18 years or older (being 18 years of age is a requirement in Eswatini for registering for MTN Mobile Money, a cell phone-based money transfer service). Those younger than 18 years could elect to either receive their incentives through the Swaziland Post and Telecommunications office, or for it to be given to the parent/guardian with the expectation that the payment would be shared with the participant. In all cases, actual payments to participants were verified telephonically (to verify that the participant received the funds).

\section{The STI raffle intervention}

Out of the study participants who were randomized to either the 'education and raffle incentive' sub-arm or the 'raffle incentive' sub-arm (Figure 2), 400 were selected every raffle round to participate in STI testing (syphilis and Trichomonas vaginalis). Participants were not excluded or reallocated if more than one individual per household was chosen. The possibility to select more than one individual per household was well understood and did not create problems during field work. OSOM Trichomonas vaginalis rapid test and Alere Determine syphilis rapid test were used to determine STI status. Positive results were provided through post-test counselling by a trained nurse. Upon being STI negative, these randomly selected participants were then eligible to win one of 80 prizes of E1000 each. For anyone with a positive rapid test, the counsellor obtained a detailed history to determine the duration of infection, including a history of previous syphilis, known contact with someone with primary or secondary syphilis, and typical signs or symptoms of syphilis in the past 12 months. Participants who tested positive for either syphilis or Trichomonas vaginalis were given treatment and retested after two weeks. If the AGYW tests negative after 2 weeks of treatment, she was eligible for selection for the next raffle round.

\section{HIV and STI counselling, testing, treatment and referral}

HIV testing consisted of the Alere Determine HIV-1/2 rapid test kit and those who were HIV positive by the Determine HIV-1/2 rapid test and/or test inconclusive received the Uni-Gold rapid test for confirmation. HIV tests were administered at study testing sites by nurses and healthcare workers certified in HIV testing and counselling. Any individual testing positive for HIV was referred to a healthcare facility for treatment. All study participants were counselled before testing by a HIV Services Testing Counsellor. Participants were tested at baseline, midline and endline each test was approximately 1 year apart. At each interaction with the study team (whether for intervention implementation or data collection), study participants were screened for gender-based violence (GBV) using a screening tool developed in 
partnership with the Eswatini Action Group Against Abuse (SWAGAA). Throughout the study, suspected GBV cases were referred to SWAGAA for follow-up and support as part of their routine counselling and support mechanisms.

\section{Data collection plan and analyses}

Data were generated from questionnaire data, education enrolment and attendance data, raffle results and laboratory results. In terms of data collection: (a) Data on education attendance were collected from routine sources using the Ministry of Education, education attendance registers, (b) In addition, spot checks were done to confirm education attendance, (c) Costing data relating to the implementation of each incentive were collected throughout the study to allow cost-effectiveness estimation as a function of the estimated HIV infections averted, and (d) Data collection for sexual behaviour was collected at baseline, midline and endline questionnaires by field data collectors. Data captured during the evaluation were uploaded using personal digital assistants (PDAs) in the field, to ensure consistent data capture across districts. Questionnaire data, education enrolment and attendance data, raffle results and laboratory results were entered into SurveyToGo and processed with a bespoke data management system developed in SQL. After validation of duplicate files, the data were then exported to a statistical package (STATA) for further cleaning and analysis.

\section{Analysis Included in this Report}

Baseline data was collected at the time of participant enrolment in 2016. The objective of the baseline data collection and analysis was twofold: describe the sociodemographic characteristics of the study population and identify variables affecting school enrolment and HIV and STI status because they could act as confounding characteristics which would need to be controlled for in the impact evaluation. The purpose of the baseline data analysis was to ascertain the following information about the study population: describe demographic characteristics; report study level education enrolment, and investigate characteristics and factors associated with education enrolment at baseline; report study level HIV and STI prevalence, and investigate relationships between background characteristics of participants, and HIV and STI status at baseline. Table 1 provides key baseline socio-demographic and descriptive evidence about the sample composition.

\section{Results}

At baseline 6,055 individuals aged 15 to 22 years were screened of which 4,863 participated in the baseline survey, 4,421 were HIV negative and 4,389 chose to enrol into the study. As designed, $50.4 \%$ of those enrolled in the study were enrolled-in-education at the start of the study with $\sim 50 \%$ in education and $\sim 50 \%$ out-of-education within each of the study groups (Table 1). As designed across the study groups $\sim 80 \%$ of the individuals were from rural enumeration areas (EAs) and $20 \%$ were from urban EAs (Table 1). Figure 3 shows the cascade from screening to enrolment for the impact evaluation. The mean age of the sample was 18.22 years (standard deviation [SD]: \pm 2.24 ). There were multiple significant differences ( $p$-value $<0.05$ ) when comparing urban versus rural individuals which included highest grade attained 
(fewer $n=182$ (20\%) AGYW attaining grades 1-7 for urban and more $n=974$ (25\%) AGYW attaining higher grades for urban $[p<0.01]$ ), never having sexual intercourse (fewer urban $n=477(53 \%)$ than rural $n=1824$ $(46 \%)$ never having intercourse $[p<0.01])$, condom use with a partner (more urban $n=242(71 \%)$ AGYW report using a condom than rural $n=1135(64 \%)$ AGYW $[p=0.02]$ ), ever giving birth (more rural $n=159$ (38\%) than urban $n=1172(55 \%)$ AGYW $[p<0.01]$ ), last sexual partner circumcised (more urban $n=152$ $(53 \%)$ AGYW than rural $n=630(40 \%)[p<0.01])$, heard of age mixing or transactional sex (both higher for rural $n=573(65 \%)$ than urban $n=2705(68 \%)[p=0.04])$, and differences in household structure including female-headed households, number of siblings, and currently married or in a union $[p<0.01]$ (Table 1$)$. Additionally, there were significant differences ( $p$-value $<0.05$ ) when comparing AGYW enrolled ineducation at the time of baseline collection and not enrolled-in-education at the time of baseline collection. These included age (older individuals being not enrolled in-education [ $p<0.01]$ ), school history (not enrolled-in-education individuals attained lower grades $[p<0.01]$ ), sexual behaviours (not enrolled-ineducation more likely of having had sexual intercourse $[p<0.01]$, experienced sexual partner age mixing $[p=0.01]$, used a condom with last partner $[p<0.01]$, received money or gift in exchange for sexual intercourse [ $p=0.03$ ], had given birth [ $<<0.01]$, sexual knowledge (not enrolled-in-education AGYW heard of HIV and had a higher level of knowledge of sexual practices than in-education AGYW) [p<0.01], and household structure differences $[p<0.01]$ (Table 1 ).

Table 1. Characteristics of adolescent girls and young women at baseline 


\begin{tabular}{|c|c|c|c|c|c|c|c|}
\hline iracteristics & $\begin{array}{c}\text { All } \\
\text { Participants } \\
(\mathbf{N}=4863)\end{array}$ & $\begin{array}{c}\text { Urban } \\
\text { (U) } \\
(\mathrm{N}=895)\end{array}$ & $\begin{array}{c}\text { Rural } \\
\text { (R) } \\
(\mathrm{N}=3968)\end{array}$ & $\begin{array}{c}\mathrm{U}=\mathrm{R} \\
\mathrm{p}- \\
\text { value }\end{array}$ & $\begin{array}{c}\text { anrolled- } \\
\text { in- } \\
\text { Education } \\
\text { (EIE) } \\
(\mathrm{N}=2337)\end{array}$ & $\begin{array}{c}\text { Not } \\
\text { a Enrolled } \\
\text { in- } \\
\text { Education } \\
\text { (NIE) } \\
(\mathrm{N}=2526)\end{array}$ & $\begin{array}{c}\text { EIE=NIE } \\
\text { p-value }\end{array}$ \\
\hline $\begin{array}{l}\text { in years } \\
\text { an (SD)) }\end{array}$ & $\begin{array}{l}18.22 \\
(2.24) \\
\end{array}$ & $\begin{array}{l}18.16 \\
(2.28) \\
\end{array}$ & $\begin{array}{l}18.24 \\
(2.24) \\
\end{array}$ & & $\begin{array}{l}16.94 \\
(1.90)\end{array}$ & $\begin{array}{l}19.40 \\
(1.86)\end{array}$ & \\
\hline 5 years (n & $\begin{array}{c}779 \\
(16.0 \%)\end{array}$ & $\begin{array}{c}143 \\
(16.0 \%)\end{array}$ & $\begin{array}{c}636 \\
(16.0 \%)\end{array}$ & \multirow[t]{8}{*}{0.16} & $\begin{array}{c}693 \\
(89.1 \%)\end{array}$ & $\begin{array}{c}86 \\
(11.0 \%)\end{array}$ & \multirow[t]{8}{*}{$<0.01$} \\
\hline 6 years (n & $\begin{array}{c}594 \\
(12.2 \%)\end{array}$ & $\begin{array}{c}134 \\
(15.0 \%)\end{array}$ & $\begin{array}{c}460 \\
(11.6 \%)\end{array}$ & & $\begin{array}{c}473 \\
(79.6 \%)\end{array}$ & $\begin{array}{c}121 \\
(20.4 \%)\end{array}$ & \\
\hline 7 years $(n$ & $\begin{array}{c}628 \\
(12.9 \%) \\
\end{array}$ & $\begin{array}{c}115 \\
(12.9 \%) \\
\end{array}$ & $\begin{array}{c}513 \\
(12.9 \%) \\
\end{array}$ & & $\begin{array}{c}405 \\
(64.5 \%) \\
\end{array}$ & $\begin{array}{c}223 \\
(35.5 \%) \\
\end{array}$ & \\
\hline 8 years (n & $\begin{array}{c}612 \\
(12.6 \%)\end{array}$ & $\begin{array}{c}104 \\
(11.6 \%)\end{array}$ & $\begin{array}{c}508 \\
(12.8 \%)\end{array}$ & & $\begin{array}{c}281 \\
(45.9 \%)\end{array}$ & $\begin{array}{c}331 \\
(54.1 \%)\end{array}$ & \\
\hline 9 years (n & $\begin{array}{c}634 \\
(13.0 \%)\end{array}$ & $\begin{array}{c}104 \\
(11.6 \%)\end{array}$ & $\begin{array}{c}530 \\
(13.4 \%)\end{array}$ & & $\begin{array}{c}194 \\
(30.6 \%)\end{array}$ & $\begin{array}{c}440 \\
(69.4 \%)\end{array}$ & \\
\hline 0 years $(n$ & $\begin{array}{c}636 \\
(13.1 \%)\end{array}$ & $\begin{array}{c}108 \\
(12.1 \%)\end{array}$ & $\begin{array}{c}528 \\
(13.3 \%)\end{array}$ & & $\begin{array}{c}143 \\
(22.5 \%)\end{array}$ & $\begin{array}{c}493 \\
(77.5 \%)\end{array}$ & \\
\hline 1 years (n & $\begin{array}{c}592 \\
(12.2 \%) \\
\end{array}$ & $\begin{array}{c}112 \\
(12.5 \%)\end{array}$ & $\begin{array}{c}480 \\
(12.1 \%)\end{array}$ & & $\begin{array}{c}98 \\
(16.6 \%)\end{array}$ & $\begin{array}{c}494 \\
(83.5 \%)\end{array}$ & \\
\hline 2 years (n & $388(8.0 \%)$ & $\begin{array}{c}75 \\
(8.4 \%) \\
\end{array}$ & $\begin{array}{c}313 \\
(7.9 \%) \\
\end{array}$ & & $\begin{array}{c}50 \\
(12.9 \%)\end{array}$ & $\begin{array}{c}338 \\
(87.1 \%) \\
\end{array}$ & \\
\hline \multicolumn{8}{|l|}{ ool history } \\
\hline \multicolumn{8}{|l|}{$\begin{array}{l}\text { hest grade } \\
\text { ined }\end{array}$} \\
\hline rade 1-7 (n & $\begin{array}{c}1156 \\
(23.8 \%)\end{array}$ & $\begin{array}{c}182 \\
(20.3 \%)\end{array}$ & $\begin{array}{c}974 \\
(24.6 \%)\end{array}$ & \multirow[t]{3}{*}{$<0.01$} & $\begin{array}{c}550 \\
(47.6 \%)\end{array}$ & $\begin{array}{c}606 \\
(52.4 \%)\end{array}$ & \multirow[t]{3}{*}{$<0.01$} \\
\hline orm 1-6 (n & $\begin{array}{c}3581 \\
(73.6 \%)\end{array}$ & $\begin{array}{c}668 \\
(74.6 \%)\end{array}$ & $\begin{array}{c}2913 \\
(73.4 \%)\end{array}$ & & $\begin{array}{c}1700 \\
(47.5 \%)\end{array}$ & $\begin{array}{c}1881 \\
(52.5 \%)\end{array}$ & \\
\hline ear 1-5 (n & $126(2.6 \%)$ & $\begin{array}{c}45 \\
(5.0 \%) \\
\end{array}$ & $81(2.0 \%)$ & & $\begin{array}{c}87 \\
(69.1 \%) \\
\end{array}$ & $\begin{array}{c}39 \\
(31.0 \%)\end{array}$ & \\
\hline $\begin{array}{l}\text { me } \\
\text { relled to } \\
\text { sol > } 30 \\
\text { utes }(\mathrm{n}(\%))\end{array}$ & $\begin{array}{c}832 \\
(36.4 \%)\end{array}$ & $\begin{array}{c}144 \\
(28.5 \%)\end{array}$ & $\begin{array}{c}688 \\
(38.6 \%)\end{array}$ & & - & - & \\
\hline \multicolumn{8}{|l|}{$\begin{array}{l}\text { ual } \\
\text { aviours }\end{array}$} \\
\hline $\begin{array}{l}\text { ever had } \\
\text { əxual } \\
\text { itercourse } \\
1(\%)) \\
\end{array}$ & $\begin{array}{c}2301 \\
(47.3 \%)\end{array}$ & $\begin{array}{c}477 \\
(53.3 \%)\end{array}$ & $\begin{array}{c}1824 \\
(46.0 \%)\end{array}$ & $<0.01$ & $\begin{array}{c}1785 \\
(77.6 \%)\end{array}$ & $\begin{array}{c}516 \\
(22.4 \%)\end{array}$ & $<0.01$ \\
\hline $\begin{array}{l}\text { Sexual } \\
\text { artner age } \\
\text { ixing (n } \\
\text { \%)) }\end{array}$ & $\begin{array}{c}428 \\
(20.3 \%)\end{array}$ & $\begin{array}{c}77 \\
(22.5 \%)\end{array}$ & $\begin{array}{c}351 \\
(19.8 \%)\end{array}$ & 0.27 & $\begin{array}{c}67 \\
(15.6 \%)\end{array}$ & $\begin{array}{c}361 \\
(84.4 \%)\end{array}$ & 0.01 \\
\hline $\begin{array}{l}\text { exual } \\
\text { ıtercourse } \\
\text { ıultiple } \\
\text { artners in } \\
\text { st } 12 \\
\text { lonths (n } \\
\text { \%)) }\end{array}$ & $25(1.2 \%)$ & $7(2.0 \%)$ & $18(1.0 \%)$ & 0.11 & $7(28.0 \%)$ & $\begin{array}{c}18 \\
(72.0 \%)\end{array}$ & 0.32 \\
\hline $\begin{array}{l}\text { ondom } \\
\text { sed with } \\
\text { ist partner } \\
\text { l }(\%))\end{array}$ & $\begin{array}{c}1377 \\
(65.1 \%)\end{array}$ & $\begin{array}{c}242 \\
(70.6 \%)\end{array}$ & $\begin{array}{c}1135 \\
(64.1 \%)\end{array}$ & 0.02 & $\begin{array}{c}334 \\
(24.3 \%)\end{array}$ & $\begin{array}{c}1043 \\
(75.7 \%)\end{array}$ & $<0.01$ \\
\hline
\end{tabular}




\begin{tabular}{|c|c|c|c|c|c|c|c|}
\hline racteristics & $\begin{array}{c}\text { All } \\
\text { Participants } \\
(\mathbf{N}=4863)\end{array}$ & $\begin{array}{c}\text { Urban } \\
(\mathrm{U}) \\
(\mathrm{N}=895)\end{array}$ & $\begin{array}{c}\text { Rural } \\
(\mathrm{R}) \\
(\mathrm{N}=3968)\end{array}$ & $\begin{array}{c}\mathrm{U}=\mathrm{R} \\
\mathrm{p}- \\
\text { value }\end{array}$ & $\begin{array}{l}\text { a }_{\text {Enrolled- }}^{\text {in- }} \\
\text { Education } \\
\text { (EIE) } \\
(\mathrm{N}=2337)\end{array}$ & $\begin{array}{c}\text { Not } \\
\text { anrolled } \\
\text { in- } \\
\text { Education } \\
\text { (NIE) } \\
(\mathrm{N}=2526)\end{array}$ & $\begin{array}{c}\text { EIE }=\text { NIE } \\
\text { p-value }\end{array}$ \\
\hline $\begin{array}{l}\text { eceived } \\
\text { loney or } \\
\text { ift in } \\
\text { xchange for } \\
\text { exual } \\
\text { itercourse } \\
1(\%))\end{array}$ & $\begin{array}{c}586 \\
(27.7 \%)\end{array}$ & $\begin{array}{c}88 \\
(25.7 \%)\end{array}$ & $\begin{array}{c}498 \\
(28.1 \%)\end{array}$ & 0.35 & $\begin{array}{c}99 \\
(16.9 \%)\end{array}$ & $\begin{array}{c}487 \\
(83.1 \%)\end{array}$ & 0.03 \\
\hline $\begin{array}{l}\text { ver given } \\
\mathrm{h}(\mathrm{n}(\%))\end{array}$ & $\begin{array}{c}1331 \\
(52.0 \%) \\
\end{array}$ & $\begin{array}{c}159 \\
(38.0 \%)\end{array}$ & $\begin{array}{c}1172 \\
(54.7 \%)\end{array}$ & $<0.01$ & 83 (6.2\%) & $\begin{array}{c}1248 \\
(93.8 \%)\end{array}$ & $<0.01$ \\
\hline $\begin{array}{l}\text { irst } \\
\text { gnancy } \\
\text { ore the age } \\
7 \text { (n (\%)) }\end{array}$ & $\begin{array}{c}505 \\
(37.9 \%)\end{array}$ & $\begin{array}{c}63 \\
(39.6 \%)\end{array}$ & $\begin{array}{c}442 \\
(37.7 \%)\end{array}$ & 0.64 & 34 (6.7\%) & $\begin{array}{c}471 \\
(93.3 \%)\end{array}$ & 0.56 \\
\hline $\begin{array}{l}\text { ast sexual } \\
\text { tner } \\
\text { umcised (n } \\
\text { l }\end{array}$ & $\begin{array}{c}782 \\
(42.3 \%)\end{array}$ & $\begin{array}{c}152 \\
(52.6 \%)\end{array}$ & $\begin{array}{c}630 \\
(40.4 \%)\end{array}$ & $<0.01$ & $\begin{array}{c}163 \\
(20.8 \%)\end{array}$ & $\begin{array}{c}619 \\
(79.2 \%)\end{array}$ & $<0.01$ \\
\hline \multicolumn{8}{|l|}{$\begin{array}{l}\text { and } \\
\text { ual } \\
\text { ctices } \\
\text { iwledge }\end{array}$} \\
\hline $\begin{array}{l}\text { eard of } \\
\text { IDS (n (\%)) }\end{array}$ & $\begin{array}{c}4702 \\
(96.7 \%)\end{array}$ & $\begin{array}{c}869 \\
(97.1 \%)\end{array}$ & $\begin{array}{c}3833 \\
(96.6 \%)\end{array}$ & 0.45 & $\begin{array}{c}2245 \\
(47.8 \%)\end{array}$ & $\begin{array}{c}2457 \\
(52.3 \%)\end{array}$ & 0.02 \\
\hline $\begin{array}{l}\text { nows that a } \\
\text { ealthy } \\
\text { 'oking } \\
\text { erson can } \\
\text { ave HIV (n } \\
\text { 'o)) } \\
\end{array}$ & $\begin{array}{c}4092 \\
(84.2 \%)\end{array}$ & $\begin{array}{c}757 \\
(84.6 \%)\end{array}$ & $\begin{array}{c}3335 \\
(84.1 \%)\end{array}$ & 0.69 & $\begin{array}{c}1915 \\
(46.8 \%)\end{array}$ & $\begin{array}{c}2177 \\
(53.2 \%)\end{array}$ & $<0.01$ \\
\hline $\begin{array}{l}\text { Heard of } \\
\text { ge } \\
\text { lixing (n } \\
\text { \%)) }\end{array}$ & $\begin{array}{c}3278 \\
(67.6 \%)\end{array}$ & $\begin{array}{c}573 \\
(64.7 \%)\end{array}$ & $\begin{array}{c}2705 \\
(68.3 \%)\end{array}$ & 0.04 & $\begin{array}{c}1503 \\
(45.9 \%)\end{array}$ & $\begin{array}{c}1775 \\
(54.2 \%)\end{array}$ & $<0.01$ \\
\hline $\begin{array}{l}\text { eard of } \\
\text { ansactional } \\
\text { ax }(\mathrm{n}(\%))\end{array}$ & $\begin{array}{c}3429 \\
(71.0 \%)\end{array}$ & $\begin{array}{c}603 \\
(68.1 \%)\end{array}$ & $\begin{array}{c}2826 \\
(71.6 \%)\end{array}$ & 0.04 & $\begin{array}{c}1596 \\
(46.5 \%)\end{array}$ & $\begin{array}{c}1833 \\
(53.5 \%)\end{array}$ & $<0.01$ \\
\hline \multicolumn{8}{|l|}{$\begin{array}{l}\text { isehold } \\
\text { ıcture }\end{array}$} \\
\hline $\begin{array}{l}\text { Iother alive } \\
1(\%))\end{array}$ & $\begin{array}{c}4057 \\
(84.0 \%)\end{array}$ & $\begin{array}{c}759 \\
(85.7 \%)\end{array}$ & $\begin{array}{c}3298 \\
(83.6 \%)\end{array}$ & 0.13 & $\begin{array}{c}2002 \\
(49.4 \%)\end{array}$ & $\begin{array}{c}2055 \\
(50.7 \%)\end{array}$ & $<0.01$ \\
\hline $\begin{array}{l}\text { ather alive } \\
1(\%))\end{array}$ & $\begin{array}{c}3189 \\
(67.0 \%)\end{array}$ & $\begin{array}{c}608 \\
(69.1 \%)\end{array}$ & $\begin{array}{c}2581 \\
(66.5 \%)\end{array}$ & 0.15 & $\begin{array}{c}1622 \\
(50.9 \%)\end{array}$ & $\begin{array}{c}1567 \\
(49.1 \%)\end{array}$ & $<0.01$ \\
\hline $\begin{array}{l}\text { emale- } \\
\text { eaded } \\
\text { ousehold (n } \\
\text { \%)) }\end{array}$ & $\begin{array}{c}1592 \\
(32.7 \%)\end{array}$ & $\begin{array}{c}336 \\
(37.5 \%)\end{array}$ & $\begin{array}{c}1256 \\
(31.7 \%)\end{array}$ & $<0.01$ & $\begin{array}{c}739 \\
(46.4 \%)\end{array}$ & $\begin{array}{c}853 \\
(53.6 \%)\end{array}$ & 0.11 \\
\hline $\begin{array}{l}\text { umber of } \\
\text { blings } \\
\text { nean (SD)) } \\
\end{array}$ & $1.46(1.2)$ & $\begin{array}{l}1.29 \\
(1.1)\end{array}$ & $1.49(1.2)$ & $<0.01$ & $1.54(1.2)$ & $1.38(1.2)$ & $<0.01$ \\
\hline
\end{tabular}




\begin{tabular}{|c|c|c|c|c|c|c|c|}
\hline Iracteristics & $\begin{array}{c}\text { All } \\
\text { Participants } \\
(\mathrm{N}=4863)\end{array}$ & $\begin{array}{c}\text { Urban } \\
(\mathrm{U}) \\
(\mathrm{N}=895)\end{array}$ & $\begin{array}{c}\text { Rural } \\
(\mathrm{R}) \\
(\mathrm{N}=3968)\end{array}$ & $\begin{array}{c}\mathrm{U}=\mathrm{R} \\
\mathrm{p}- \\
\text { value }\end{array}$ & $\begin{array}{c}\text { atenrolled- } \\
\text { in- } \\
\text { Education } \\
\text { (EIE) } \\
(\mathrm{N}=2337)\end{array}$ & $\begin{array}{c}\text { Not } \\
\text { anrolled } \\
\text { in- } \\
\text { Education } \\
(\text { NIE) } \\
(\mathrm{N}=2526)\end{array}$ & $\begin{array}{c}\mathrm{EIE}=\mathrm{NIE} \\
\text { p-value }\end{array}$ \\
\hline $\begin{array}{l}\text { urrently } \\
\text { tarried or } \\
\text { t union (n } \\
\text { \%)) }\end{array}$ & $115(2.4 \%)$ & $\begin{array}{c}11 \\
(1.2 \%)\end{array}$ & $\begin{array}{c}104 \\
(2.6 \%)\end{array}$ & 0.01 & $0(0.0 \%)$ & $\begin{array}{c}115 \\
(100.0 \%)\end{array}$ & $<0.01$ \\
\hline
\end{tabular}

a Enrolled in education: This variable corresponds to if an individual said she was enrolled in education at the time of the interview

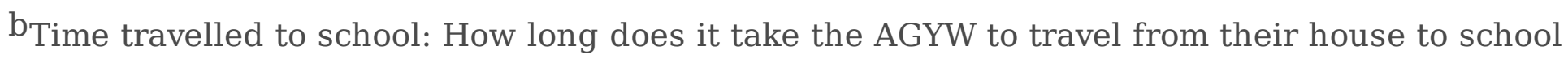
regardless of the time of day in minutes. Not answered by those not enrolled in education.

${ }^{\mathrm{C}}$ Age mixing defined as having sexual intercourse with an individual 10 years or older than one's self in the last 12 months

P-value are generated to show if there was a significant difference in Reponses between urban versus rural, and comparing enrolled in school and not enrolled in school; significant observation ( $p$-value $<0.05$ ) are bolded

Responses of "Don't know," "Refuse to answer," and "Not Applicable" are not included in this table. Missing values due to skip patterns are also not included in this table.

Column totals and percentages were calculated for locality, and row totals and percentages were calculated for in-school versus out-of-school

Over half (52.7\%) of the AGYW surveyed at baseline had their sexual debut. Additionally, 20.3\% of AGYW who had sexual intercourse in the past 12 months, experienced age mixing (sexual intercourse in the last 12 months with an individual more than 10 years older than themselves), and $27.7 \%$ indicated that they had sexual intercourse in the exchange of money or gifts (Table 1). $32.7 \%$ of households were headed by females (Table 1). Very few (2.4\%) AGYW were married or in a union at baseline (Table 1).

The baseline prevalence of HIV, Trichomonas vaginalis, and syphilis among AGYW were $8.20 \%$ $(397 / 4,840), 3.31 \%(150 / 4,533)$ and $0.17 \%(8 / 4,830)$ respectively (Table 2$)$. The baseline prevalence of HIV among those enrolled-in-education was 3.7\% (86/2,326) compared to $12.37 \%(311 / 2,514)$ among those not enrolled-in-education (Table 2). The baseline prevalence of Trichomonas vaginalis among those enrolled-in-education was $1.25 \%(27 / 2,153)$ compared to $5.17 \%(123 / 2,380)$ not enrolled-ineducation. The baseline prevalence of syphilis among those enrolled-in-education was $0.09 \%(2 / 2,323)$ compared to $0.24 \%(6 / 2,507)$ not enrolled-in-education.

Table 2. Prevalence of HIV, syphilis, and Trichomonas vaginalis among adolescent girls and young women at baseline 


\begin{tabular}{|c|c|c|c|c|c|c|}
\hline $\begin{array}{c}\text { Laboratory- } \\
\text { confirmed STI }\end{array}$ & $\begin{array}{l}\text { Number } \\
\text { (n) }\end{array}$ & $\begin{array}{l}\text { Prevalence } \\
\%(n / N)\end{array}$ & $\begin{array}{c}\text { In- } \\
\text { education } \\
\text { at } \\
\text { Baseline }\end{array}$ & $\begin{array}{c}\text { Out-of- } \\
\text { education at } \\
\text { Baseline }\end{array}$ & Rural & Urban \\
\hline HIV & 397 & $\begin{array}{c}8.20 \\
(397 / 4840) *\end{array}$ & $\begin{array}{c}3.70 \\
(86 / 2326)\end{array}$ & $\begin{array}{c}12.37 \\
(311 / 2514)\end{array}$ & $\begin{array}{c}7.92 \\
(313 / 3,950)\end{array}$ & $\begin{array}{c}9.44 \\
(84 / 890)\end{array}$ \\
\hline $\begin{array}{l}\text { Both HIV and } \\
\text { Syphilis }\end{array}$ & 4 & $\begin{array}{c}0.08 \\
(4 / 4827)\end{array}$ & $\begin{array}{c}0.04 \\
(1 / 2322)\end{array}$ & $\begin{array}{c}0.12 \\
(3 / 2505)\end{array}$ & $\begin{array}{c}0.08 \\
(3 / 3938)\end{array}$ & $\begin{array}{c}0.11 \\
(1 / 889)\end{array}$ \\
\hline $\begin{array}{l}\text { Both HIV and } \\
\text { Trichomonas } \\
\text { vaginalis }\end{array}$ & 50 & $\begin{array}{c}1.10 \\
(50 / 4531)\end{array}$ & $\begin{array}{c}0.23 \\
(5 / 2153)\end{array}$ & $\begin{array}{c}1.89 \\
(45 / 2378)\end{array}$ & $\begin{array}{c}0.91 \\
(34 / 3727)\end{array}$ & $\begin{array}{c}1.99 \\
(16 / 804)\end{array}$ \\
\hline $\begin{array}{l}\text { Trichomonas } \\
\text { vaginalis }\end{array}$ & 150 & $\begin{array}{c}3.31 \\
(150 / 4533) \\
\end{array}$ & $\begin{array}{c}1.25 \\
(27 / 2153) \\
\end{array}$ & $\begin{array}{c}5.17 \\
(123 / 2380) \\
\end{array}$ & $\begin{array}{c}3.41 \\
(127 / 3729) \\
\end{array}$ & $\begin{array}{c}2.86 \\
(23 / 804) \\
\end{array}$ \\
\hline Syphilis & 8 & $\begin{array}{c}0.17 \\
(8 / 4,830)\end{array}$ & $\begin{array}{c}0.09 \\
(2 / 2323)\end{array}$ & $\begin{array}{c}0.24 \\
(6 / 2507)\end{array}$ & $\begin{array}{c}0.15 \\
(6 / 3941)\end{array}$ & $\begin{array}{c}0.23 \\
(2 / 889)\end{array}$ \\
\hline $\begin{array}{l}\text { Both Syphilis } \\
\text { and } \\
\text { Trichomonas } \\
\text { vaginalis }\end{array}$ & 3 & $\begin{array}{c}0.07 \\
(3 / 4532)\end{array}$ & $\begin{array}{c}0.05 \\
(1 / 2152)\end{array}$ & $\begin{array}{c}0.08 \\
(2 / 380)\end{array}$ & $\begin{array}{c}0.03 \\
(1 / 3728)\end{array}$ & $\begin{array}{c}0.25 \\
(2 / 804)\end{array}$ \\
\hline
\end{tabular}

*23 individuals without HIV test results; 330 individuals without Trichomonas vaginalis test results; 33 individuals without Syphilis test results

Factors in Table 3 that were significantly associated with increased risk of HIV infection at baseline were older age, not being enrolled in education. It should be noted that sexual partner age mixing was an extremely strong predictor of HIV with only $0.1 \%(2 / 1,685)$ of AGYW who did not engage in age mixing testing HIV positive while $65.5 \%$ (275/420) of AGYW who did engage in age mixing tested HIV positive.

Table 3. Factors associated with HIV infection in adolescent girls and young women at baseline 


\begin{tabular}{|c|c|c|}
\hline Factors & OR (95\% CI) & p-value \\
\hline \multicolumn{3}{|l|}{ a Age in years } \\
\hline 19-22 years & $3.24(2.60-4.04)$ & $<0.01$ \\
\hline \multicolumn{3}{|l|}{ Locality } \\
\hline Rural & $0.82(0.64-1.05)$ & 0.12 \\
\hline \multicolumn{3}{|l|}{ School history } \\
\hline $\mathrm{b}_{\text {Enrolled in education }}$ & $0.30(0.24-0.37)$ & $<0.01$ \\
\hline \multicolumn{3}{|l|}{${ }^{{ }^{C} \text { Highest grade attained }}$} \\
\hline Grade 1-7 & 1 & \\
\hline Form 1-6 & $0.56(0.45-0.70)$ & $<0.01$ \\
\hline Year 1-5 & $0.61(0.31-1.18)$ & 0.14 \\
\hline$>30$ minutes to travel to school & $1.02(0.67-1.56)$ & 0.92 \\
\hline \multicolumn{3}{|l|}{ Sexual behaviours } \\
\hline Had sexual intercourse & $4.18(3.26-5.36)$ & $<0.01$ \\
\hline CSexual partner age mixing & $>100.00(346.5-3459.4)$ & $<0.01$ \\
\hline Sexual intercourse with multiple partners in last 12 months & $2.04(0.81-5.15)$ & 0.13 \\
\hline Condom used with last sexual partner & $0.73(0.57-0.94)$ & 0.02 \\
\hline Received money of gift in exchange for sexual intercourse & $1.08(0.82-1.42)$ & 0.60 \\
\hline Ever given birth & $1.45(1.15-1.83)$ & $<0.01$ \\
\hline$<17$ years old for first pregnancy & $1.31(0.96-1.77)$ & 0.09 \\
\hline Last sexual partner circumcised & $0.98(0.76-1.28)$ & 0.91 \\
\hline HIV and Sexual Practices Knowledge & & \\
\hline Heard of AIDS & $1.08(0.61-1.92)$ & 0.80 \\
\hline Does not know that a healthy looking person can have HIV & $0.97(0.74-1.28)$ & 0.84 \\
\hline Heard of age mixing & $1.08(0.87-1.34)$ & 0.49 \\
\hline
\end{tabular}




\begin{tabular}{|l|c|c|}
\hline Factors & OR (95\% CI) & p-value \\
\hline Head of transactional sex & $1.33(1.05-1.68)$ & $\mathbf{0 . 0 2}$ \\
\hline Syphilis and Trichomonas vaginalis status & & \\
\hline & & \\
\hline Has syphilis & $10.84(6.21-18.92)$ & $<0.01$ \\
\hline & & \\
\hline Has Trichomonas vaginalis & $1.82(1.59-2.09)$ & $<0.01$ \\
\hline Household structure & & \\
\hline & & \\
\hline Mother deceased & $1.85(1.46-2.34)$ & $<0.01$ \\
\hline & & \\
\hline Father deceased & $1.56(0.27-1.92)$ & $<0.01$ \\
\hline & & \\
\hline Female-headed household & $1.09(0.88-1.34)$ & 0.41 \\
\hline Number of siblings & & \\
\hline No siblings & 1 & \\
\hline 1 sibling & $0.56(0.42-0.74)$ & $<0.01$ \\
\hline 2 siblings & $0.63(0.47-0.84)$ & $<0.01$ \\
\hline$>2$ siblings & $0.67(0.52-0.86)$ & $<0.01$ \\
\hline & $3.40(2.18-5.30)$ & $<0.01$ \\
\hline Currently married or in union
\end{tabular}

OR: odds ratio

CI: confidence interval

Significant observation ( $\mathrm{p}$-value $<0.05$ ) are bolded

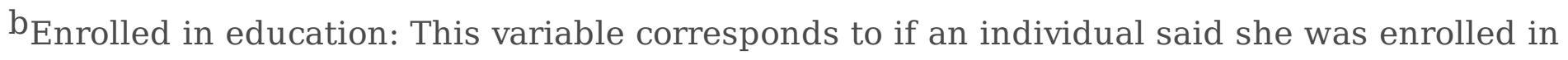
education at the time of the interview

${ }^{\mathrm{C}}$ Age mixing defined as having sexual intercourse with an individual 10 years or older than one's self in the last 12 months

Responses of "Don't know," "Refuse to answer," and "Not Applicable" are not included in this table. Missing values due to skip patterns are also not included in this table

Factors in Table 3 that were significantly associated with decreased risk of HIV infection at baseline were being enrolled-in-education, higher grade of attainment, condom use with last partner, not having a deceased parent and having siblings.

\section{Discussion}

At baseline, the impact evaluation was able to meet the evaluation protocol objectives. Participants consisted of $50 \%$ in education and $50 \%$ out-of-education AGYW at baseline, $80 \%$ rural and $20 \%$ urban and there was balance obtained across study sub-arms. Additionally, all ethical considerations were 
maintained including informed consent and HIV/STI counselling. The impact evaluation was able to obtain good internal validity by successfully enrolling the required number of participants into the study and was able to achieve balance amongst the study arms and sub-arms. The impact evaluation was also able to provide good external validity through its in-depth collection of demographic information, HIV and STI prevalence. Beyond meeting protocol and design objectives the baseline survey provided insights into HIV risk factors for AGYW in Eswatini.

Comparing previous country surveys to the baseline survey was challenging because of the difference in age populations being surveyed. The Multiple Indicator Cluster Survey (MICS)(16) focused on those aged 15-49 years of age rather than stratifying by age group. Comparable findings were found when comparing the baseline survey to the Eswatini HIV Estimates and Projections Report 2015(2), even though this report consists of modelled estimates and not HIV prevalence data. The Eswatini HIV Estimates and Projections Report estimated HIV prevalence to be $6 \%$ and $8 \%$ among females aged 15-19 and 20-24 years respectively, where the impact evaluation baseline survey found that $8.2 \%$ of $15-22$ year old females surveyed tested positive for HIV which is in line with previous study estimates. This gives confidence in the sample and allows for the potential impact to be compared against other programs.

There were some differences and similarities when comparing the structure of Sitakhela Likusasa and other financial incentive studies focused on HIV prevention. Baird et al. in Malawi also included out-ofeducation girls(11) which is a primary focus of Sitakhela Likusasa because out-of-education girls are more likely to be sexually active and have older sexual partners.(4,7) Additionally, Eswatini has a much lower secondary school attendance that South Africa and other Southern African countries.(17) Both CAPRISA 007 and HPTN 068 financial incentive studies did not recruit out-of-education girls. $(13,15)$ Both CAPRISA 007 and Baird et al. Malawi studies used cluster designs and Sitakhela Likusasa followed this practice. $(11,13)$ When comparing the financial incentives provided in CAPRISA 007 versus Sitakhela Likusasa, the total possible amount of incentives was lower in Sitkhela Likusasa (E1400 in Sitakhela Likusasa vs R1750 in CAPRISA per year)(13), but there was a wider range of opportunities to earn education incentives in Sitakhela Likusasa: e.g., primary/secondary education attendance/enrolment, exam sitting, completion of short-courses, etc.

In a more detailed comparison of baseline results CAPRISA enrolled 2,949 individuals, $52.8 \%$ were females, mean age was 16.8 years, mean age at sexual debut was 15 years, $31.1 \%$ were sexually active and HIV prevalence was 4.2\%.(13) The Sitakhela Likusasa has more individuals enrolled, a slightly older study population, were older at first sexual debut, has more are sexually active participants and a higher HIV prevalence at baseline.

HPTN 068 enrolled a total of 2,533 participants with the median age of 15 years, $3.2 \%$ tested HIV positive, $8.9 \%$ were ever pregnant, $26.6 \%$ ever had sexual intercourse, $6.6 \%$ had sexual intercourse before the age of 15 years, $19.7 \%$ had a sexual partner over 5 years older, $14.2 \%$ engaged in transactional sexual intercourse, $19.2 \%$ had concurrent sexual relationships, $9.8 \%$ reported sexual abuse, and $6.6 \%$ of those enrolled in school missed more than 5 days of school.(15) At baseline, ever being pregnant, ever having 
sexual intercourse, early age debut, sexual intercourse with a sexual partner over 5 years older and engaging in transaction sexual intercourse were all significantly ( $p$-value $<0.05$ ) associated with HIV infection when holding all other factors constant.(15) Sitakhela Likusasa has an older participant population, more AGYW testing positive for HIV, a similar number were ever pregnant, fewer individuals had sexual intercourse with older partners, fewer individuals had concurrent sexual partnerships, more reported sexual abuse, and more individuals missed more days of school. Similar factors were significantly associated ( $p$-value $<0.05$ ) with HIV infection including ever having sexual intercourse and sexual intercourse with an older sexual partner.

At baseline RESPECT enrolled 2,399 individuals where $50.2 \%$ were females and the mean age was 27.5 years. $10.4 \%$ of those enrolled achieved an education level above primary school. (14) Most of the individuals enrolled were married (74.7\%). $12.4 \%$ of individuals at baseline tested positive for trichomonas, $1.7 \%$ tested positive for syphilis and 3.5\% tested positive for HIV.(14) In comparison, in Sitakhela Likusasa more individuals were enrolled in school, all are females, the mean age was 18.2 years, more $(\sim 76 \%)$ had education levels above primary school but only $4.6 \%$ were married or in a union because the surveyed population was on average $\sim 10$ years younger.

The strengths of the Sitakhela Likusasa Impact Evaluation design are: a $2 \times 2$ factorial design that combines a cash incentive for education enrolment and attendance, and a raffle incentive conditional on remaining STI free; concentration on rural populations ( $80 \%$ allocation) compared to urban populations ( $20 \%$ allocation); enrolling $50 \%$ of adolescent girls and young women (AGYW) currently enrolled in education, and $50 \%$ of AGYW not currently enrolled in education; and HIV incidence as a primary endpoint; and multiple secondary outcomes (education enrolment and attendance at endline, changes in reported sexual behaviours between baseline and endline, endline prevalence of Trichomonas vaginalis and syphilis, and education attendance and graduation rates).

Many of the study participants achieved Forms 1-6 (73.6\%), but only $2.6 \%$ attained education above Form 5 or 6 . Higher education attainment was associated with a $74 \%$ reduced risk of HIV infection and a $75 \%$ reduction of risk of Trichomonas vaginalis infection. Potential barriers which may affect students staying in school are some of the sexual behaviour of the population which include age mixing, sexual intercourse with more than 1 partner in the last 12 months and having sexual intercourse with non-regular partners. Therefore, the incentives paid for school attendance and remaining STI free in this study might have an impact in behaviour.

The study has some limitations including first the challenges of tracking and tracing the population under study. Adolescent girls and young women aged 15-22 years are mobile and may be challenging to reach if they are sharing cell phones, and constantly changing numbers. The requirement that $50 \%$ of the enrolled population be out-of-school contributes to the risk of losing study participants which could lead to losing power to detect a difference of the intervention. Additionally, the behavioural variables analysed are self-reported and some specific risk factors may be under reported within this cohort and vary from other country level studies. This paper presents a broad description of a cohort of adolescent girls and 
young women and identifies key socio-demographic and behavioural factors associated with HIV and curable STIs which will be further evaluated at the end of the study as factors associated with HIV incidence.

\section{Conclusions}

Adolescent girls and young women in Eswatini are at high risk for HIV infection. Providing educational incentives offers one mechanism to address various factors that increase the risk of HIV acquisition. Previous studies have shown that education may reduce HIV risk through: increased exposure to information about HIV and prevention methods $(18,19)$; improved cognitive skills to make complex decisions (20); better financial security (21-24), reducing participation in transactional sex for women (11); and the ability to match with lower risk sex partners (25-27). This is the first impact evaluation of its size which has recruited $50 \%$ out-of-school adolescent girls and young women and expanded educational incentives to include multiple forms of education not just traditional primary and secondary schooling. This study will provide further validation on the ability of educational incentives impact on HIV acquisition and will allow for a better understanding of specific risk factors contributing to HIV acquisition among this high-risk population. This impact evaluation provides additional focus on a vulnerable population, out-of-school adolescent girls and young women, and targets this population even though they are hard to reach.

\section{Abbreviations}

PLHIV - People living with HIV

UNFPA - United Nations Populations Fund

STI - Sexually transmitted infection

HIV - Human immunodeficiency virus

HSV-2 - Herpes simplex virus type 2

AGYW - Adolescent girls and young women

EA - Enumeration area

OVC - Orphans and vulnerable children

NERCHA - National Emergency Response for HIV/AIDS

$E$ - Emalangeni

USD - United States dollar 
GBV - Gender-based violence

SWAGAA - Eswatini Action Group Against Abuse

PDA - Personal digital assistants

WIRB - Western Institutional Review Board

SD - Standard deviation

\section{Declarations}

Ethics approval and consent to participate: All research included in this manuscript has been performed in accordance with the Declaration of Helsinki and was approved by two ethics committees, Western Institutional Review Board and the National Health Research Board of Eswatini. Ethics approval and consent to participate. Ethical approval for the study was sought from the National Health Research Board of the Eswatini Ministry of Health and from the Western Institutional Review Board (WIRB). Participants (or their caregivers, if under 18) first consented using written consent (or assented if younger than 18) to be part of baseline data collection. It was explained to them that if they were HIV negative, they would be invited to enrol in the study. Not all HIV negative participants chose to enrol in the study. The purpose of the study, the outcomes, and process, and the confidentiality of their responses were explained to all potential participants and their caregivers (for participants under the age of 18 years). Participants under 18 had to sign a separate assent form. They received an information sheet detailing risks and benefits of enrolment and invited to participate in baseline data collection. Their informed consent was obtained in local language at a designated study site. All participants were allowed to refuse to participate or leave the study at any time. The signed informed consent forms and assent forms from participants and caregivers were retained and a copy left for the individual (and their caregiver, if applicable). Communities were sensitized through traditional structures/community leaders. Caregivers were not informed of HIV testing results for minors as the age of consent for HIV testing in Eswatini is 12 years (as per Eswatini's Integrated HIV Management Guidelines 2015)(28). This minimized the chance that caregivers would be able to deduce that the minor was excluded due to their HIV status for those minors who do not wish to disclose their status to the guardians.

Consent to publish: Not applicable

Availability of data and materials: The datasets used and/or analyzed during the current study are available from the corresponding author on reasonable request.

Competing interests: No competing interests

Funding: Ministry of Finance of the Government of the Kingdom of Eswatini; UKAID (Department for International Development, United Kingdom); United Nations Joint Programme on HIV/AIDS (UNAIDS); and The Global Fund to Fight AIDS, TB and Malaria. 
The funding bodies played no role in the design of the study and collection, analysis, and interpretation of data and in writing the manuscript.

Authors Contributions: Authors MG, AL1, SK, MN, TD, MM, KS, VT, MD, FL, WH, AL2, PH, DW, and KM have made substantial contributions to the conception, design of the study, acquisition of the analysis, interpretation of the data, and have drafted the manuscript and revised it.

Acknowledgements: Not applicable

\section{References}

1. Wang H, Wolock TM, Carter A, Nguyen G, Kyu HH, Gakidou E, et al. Estimates of global, regional, and national incidence, prevalence, and mortality of HIV, 1980-2015: the Global Burden of Disease Study 2015. The lancet HIV. 2016;3(8):e361-e87.

2. The National Emergency Response Council on HIV and AIDS. Swaziland and HIV Estimates and Projections Report 2015.

3. UNICEF. Swaziland Multiple Indicator Cluster Survey 2010 Final Report. December; 2011.

4. Jameson S, Lungile L, Sabelo D, Shabalala-Zwane, F, Londiwe D. The effectiveness of media programs on HIV and AIDS in Swaziland. Journal of Harmonized Research in Medical \& Health Sci.. 2015;2(4):183-192.

5. Central Statistics Office. Swaziland Household Income and Expenditure Survey (SHIES)- Poverty in a decare of slow economic growth- Swaziland in the 2000's. 2011.

6. Force PRT. The Swaziland Poverty reduction strategy and action plan (PRSAP). 2007.

7. Fielding-Miller R, Dunkle K, Jama-Shai N, Windle M, Hadley C, Cooper H. The feminine ideal and transactional sex: Navigating respectability and risk in Swaziland. Social Science \& Medicine. 2016;158:24-33.

8. Hajizadeh M, Sia D, Heymann SJ, Nandi A. Socioeconomic inequalities in HIV/AIDS prevalence in sub-Saharan African countries: evidence from the Demographic Health Surveys. International journal for equity in health. 2014 Dec;13(1):18.

9. World Bank Group [Internet]. GINI Index (World Bank Estimate); 2017 [cited 2020 February 10]. Available from: https://data.worldbank.org/indicator/SI.POV.GINI

10. United National Population Fund Eswatini [Internet]. Gender-based Violence; 2020 [cited 2020 February 10]. Available from: https://eswatini.unfpa.org/en/topics/gender-based-violence-2

11. Baird SJ, Garfein RS, McIntosh CT, Özler B. Effect of a cash transfer programme for schooling on prevalence of HIV and herpes simplex type 2 in Malawi: a cluster randomised trial. The Lancet. 2012;379(9823):1320-9.

12. Björkman Nyqvist $M$, Corno $L$, de Walque $D$, Svensson J. Using lotteries to incentivize safer sexual behavior: evidence from a randomized controlled trial on HIV prevention. 2015. 
13. Karim QA, Leask K, Kharsany A, Humphries H, Ntombela F, Samsunder N, et al., editors. Impact of conditional cash incentives on HSV-2 and HIV prevention in rural South African high school students: results of the CAPRISA 007 cluster randomized controlled trial. Journal of The International AIDS Society; 2015: International AIDS Society Avenue De France 13, Geneva, 1202, Switzerland.

14. De Walque D, Dow WH, Nathan R, Abdul R, Abilahi F, Gong E, et al. Incentivising safe sex: a randomised trial of conditional cash transfers for HIV and sexually transmitted infection prevention in rural Tanzania. BMJ open. 2012;2(1):e000747.

15. Pettifor A, MacPhail C, Selin A, Gómez-Olivé FX, Rosenberg M, Wagner RG, et al. HPTN 068: a randomized control trial of a conditional cash transfer to reduce HIV infection in young women in South Africa-study design and baseline results. AIDS and Behavior. 2016;20(9):1863-82.

16. Central Statistical Office. 2015 Swaziland Multiple Indicator Cluster Survey 2014, Key Findings. Mbabane, Swaziland: Central Statistical Office

17. World Bank Group. Saber Country Report: Swaziland. 2016.

18. Agüero J, Bharadwaj P. Do the More Educated Know More about Health? Evidence from Schooling and HIV Knowledge in Zimbabwe. Econ Devel Cult Change. 2014;62(3)

19. de Walque D. Does Education Affect HIV Status? Evidence from five African Countries. World Bank Econ Rev. 2009;23(2):209-233.

20. Cutler DM, Lleras-Muney A. Understanding differences in health behaviors by education. Journal of health economics. 2010;29(1):1-28.

21. Psacharopoulos G. Returns to Investment in Education - a Global Update. World Dev. 1994;22(9):1325-1343.

22. Schultz TW. Capital Formation by Education. J Polit Econ. 1960;68(6):571-583.

23. Siphambe HK. Rates of return to education in Botswana. Econ Educ Rev. 2000;19(3):291-300.

24. Willis RJ. A new approach to the economic theory of fertility behavior. J Polit Econ. 1973;81(2)

25. Behrman JR, Rosenzweig MR. Does Increasing Women's Schooling Raise the Schooling of the Next Generation? American Economic Review. 2002;92(1):323-334.

26. Bosma H, Appels A, Sturmans F, Grabauskas V, Gostautas A. Educational level of spouses and risk of mortality: the WHO Kaunas-Rotterdam Intervention Study (KRIS) International journal of epidemiology. 1995;24(1):119-126.

27. Pettifor AE, Rees HV, Kleinschmidt I, et al. Young people's sexual health in South Africa: HIV prevalence and sexual behaviors from a nationally representative household survey. Aids. 2005;19(14):1525-1534.

28. Swaziland Ministry of Health. 2015 Swaziland Integrated HIV Management Guidelines. Mbabane, Swaziland: Ministry of Health

\section{Figures}




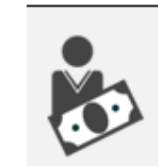
TREATMENT ARM: SUB-ARM 1: EI \& RAFFLE EDUCATION INCENTIVES (EI) AND INTENSIFIED INTERVENTION

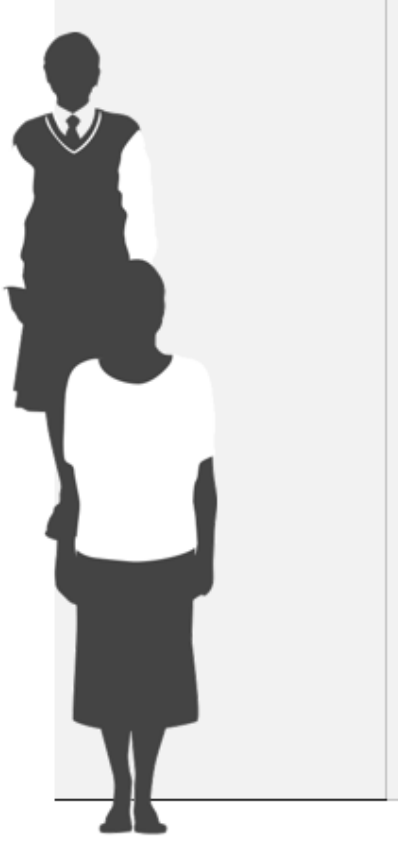

Education incentive for enrolling in and attending public or private school in Eswatini:

- Enrol in-school in Eswatini in 2016 - 2018; then receive cash incentive (E200 per year)

- If in-school with $80 \%$ or higher attendance for each school term; then receive cash incentive per term (E400 per term)

Education incentive for initiating and completing upgrading classes:

- Enrol for upgrading classes in Eswatini; then receive $\mathrm{E} 700$ for the year

- Apply for SGCSE exams; then receive E700 for the year

Education incentive for initiating and sitting for exams at University, vocational school or technical college:

- Register at University or College within Eswatini for 2016 - 2018; then receive cash incentive (E700 per year)

- Sit for the annual exam at the end of the year; then receive cash incentive (E700 per year)

Education incentive for initiating and completing a short course of any kind:

- Initiate attendance at short course during 2016 - 2018 through proof of payment; then receive cash incentive (E700 per course)

- Complete the short course; then receive cash incentive (E700 per course)

\section{SUB-ARM 2: EI ONLY}

Education incentive for enrolling in and attending public or private school in

Eswatini:

- Enrol in-school in Eswatini in 2016 . 2018; then receive cash incentive (E200 per year)

- If in-school with $80 \%$ or higher attendance for each school term; then receive cash incentive per term (E400 per term)

Education incentive for initiating and completing upgrading classes:

- Enrol for upgrading classes in Eswatini; then receive E700 for the year

- Apply for SGCSE exams; then receive $\mathrm{E} 700$ for the year

Education incentive for initiating and sitting for exams at University, vocational school or technical college:

- Register at University or College within Eswatini for 2016 - 2018; then receive cash incentive (E700 per year)

- Sit for the annual exam at the end of the year; then receive cash incentive (E700 per year)

Education incentive for initiating and completing a short course of any kind:

- Initiate attendance at short course during 2016 - 2018 through proof of payment; then receive cash incentive (E700 per course)

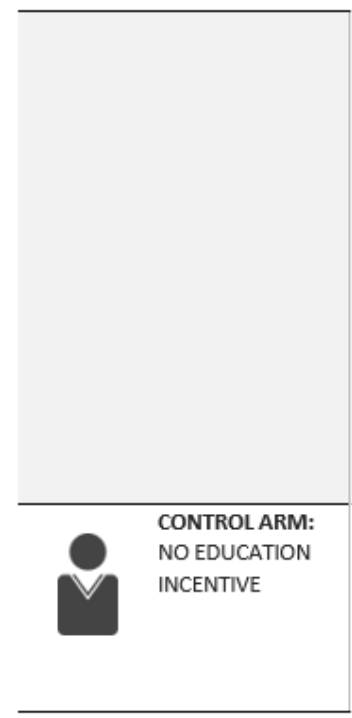

Intensified fee subsidy intervention for education (OOSY-ii) for participants returning to school in 2018 (for those who indicated at midline, that in 2017 they were out-of-school):

- Enrol to return to a public school or for an upgrading class, or register for a public University or College or to attend a short course; then apply for your 2018 school fees, to a limit of E 2900 for the year, to be paid directly to the school, college or university where registered.

Raffle:

- If randomly selected for STI screening and participant tests negative for Trichomonas Vaginalis and Syphilis; then possible incentive through raffle prize draw (E1 000 per raffle) SUB-ARM 3: RAFFLE ONLY

- If randomly selected for STI screening and participant tests negative for Trichomonas Vaginalis and Syphilis; then possible incentive through raffle prize draw (E1 000 per raffle)
- Complete the short course; then receive cash incentive (E700 per course)

Intensified fee subsidy intervention for education (OOSY-ii) for participants returning to school in $\mathbf{2 0 1 8}$ (for those who indicated at midline, that in 2017 they were out-of-school):

- Enrol to return to a public school or for an upgrading class or register for a public University or College or to attend a short course; then apply for your 2018 school fees, to a limit of $E$ 2900 for the year, to be paid directly to the school, college or university where registered.

SUB-ARM 4: CONTROL

- No education incentive

- No participation in raffle

- No intensified fee subsidy intervention

\section{Figure 1}

Description of impact evaluation and sub arms, with interventions assigned to each group 


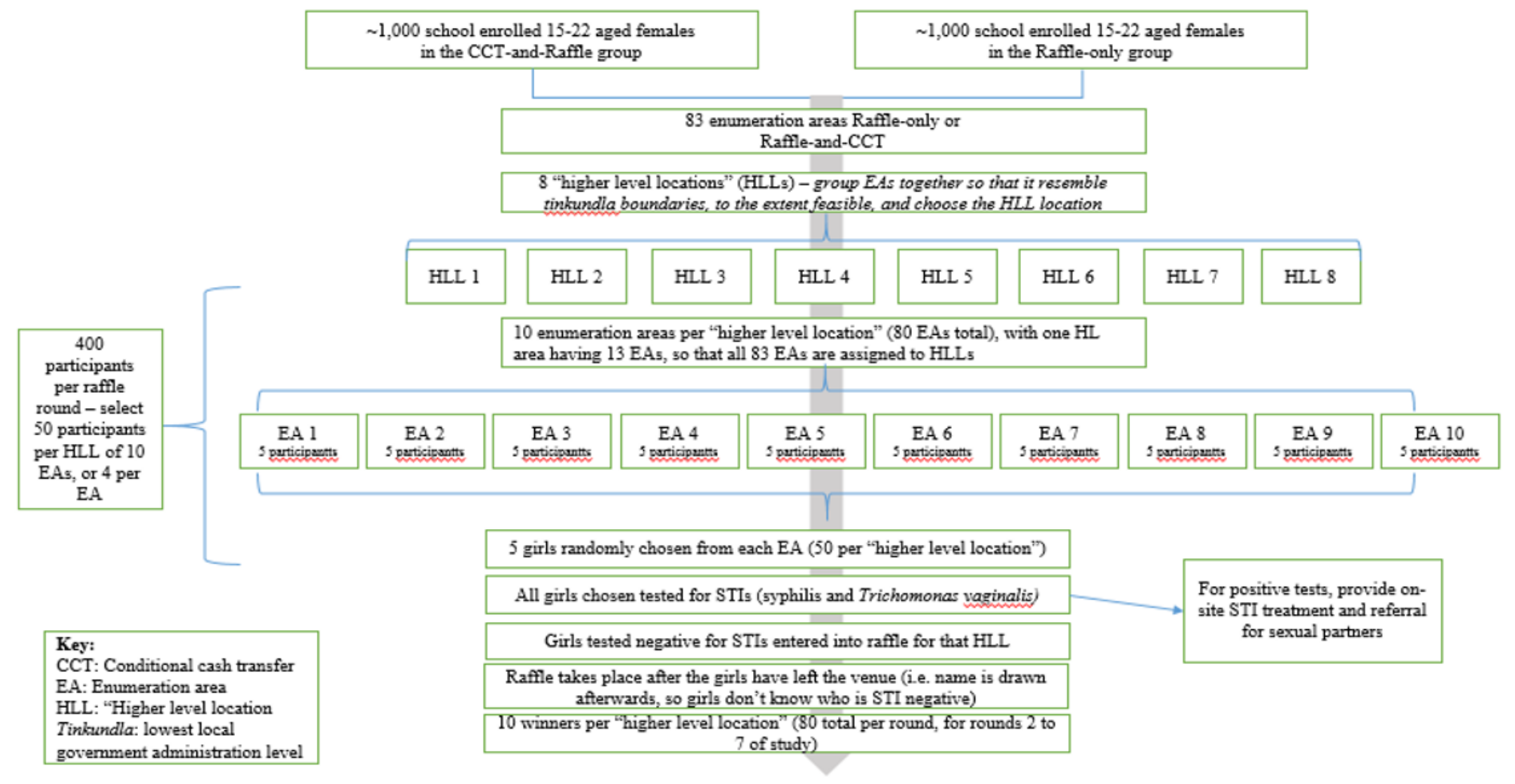

All participants are eligible to win subsequent raffle rounds and all winners are paid E1000 within 2 weeks after raffle, at every round.

\section{Figure 2}

Raffle Intervention Procedure during rounds 2 to 7

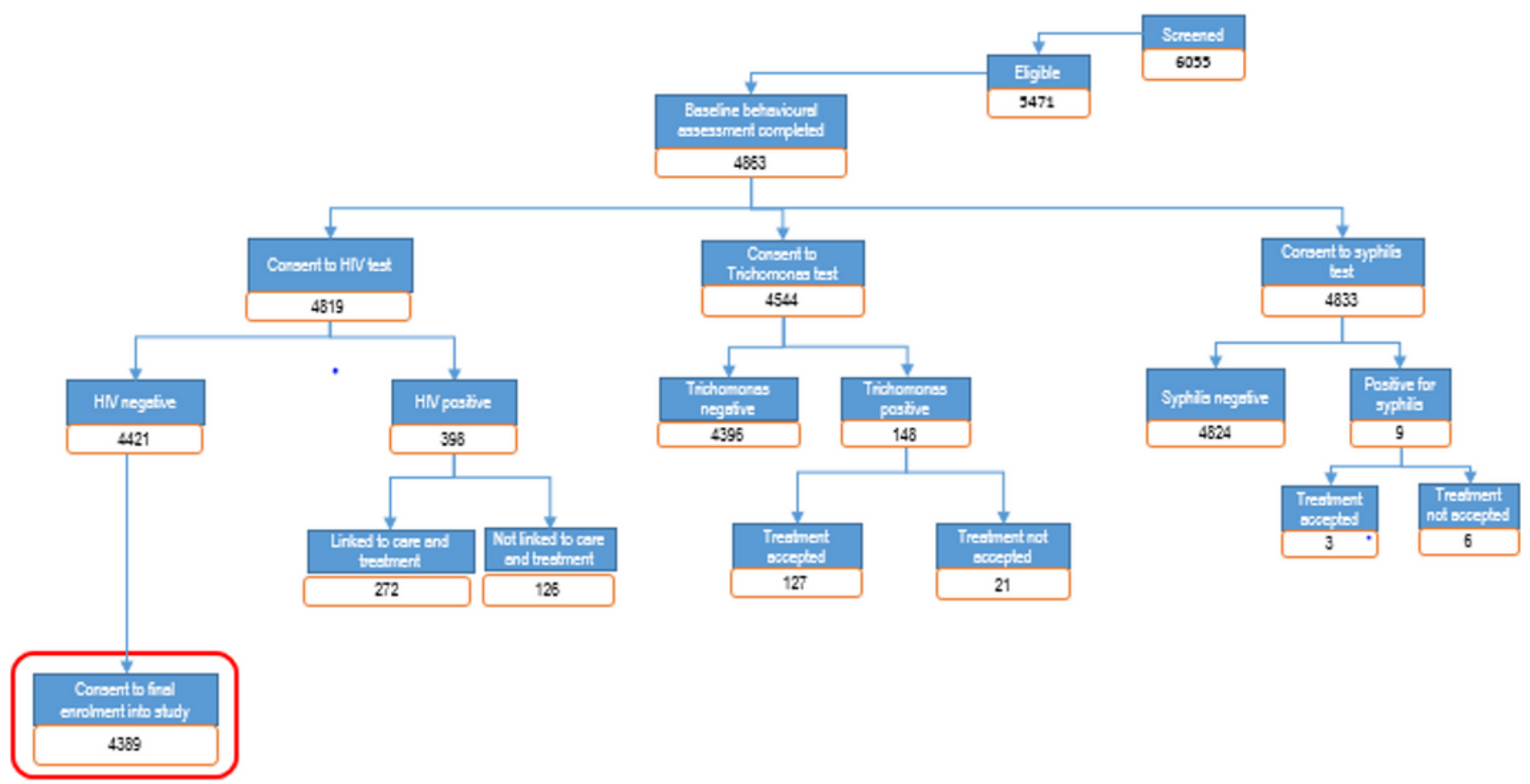


Figure 3

Baseline enrolment cascade

\section{Supplementary Files}

This is a list of supplementary files associated with this preprint. Click to download.

- SupplementalTables.docx

- CONSORT2010Checklist4May2020.doc 